\title{
Mathematization and Vergessenmachen in the Historiography of Logic
}

\author{
Lorenz Demey, University of Leuven
}

Forthcoming in History of Humanities, vol. 5, no. 1 (2020).

\begin{abstract}
A B S T R A C T
In this essay, I argue that the mathematization of logic toward the end of the nineteenth century led to a clear case of what the sociologist of science Oliver Dimbath has called Vergessenmachen. Several pioneers of the mathematical tradition deemed their approach far superior to the earlier Aristotelian (and especially medieval) tradition in logic. They attempted to push this earlier work into oblivion, by treating it with (often extreme) hostility. Due to this process of scholarly forgetting, certain new steps in logical research - which required bringing together elements from the Aristotelian and mathematical approaches - were taken at a very slow pace, and often only after being instigated or catalyzed by disciplinary outsiders, for whom the earlier Aristotelian tradition had not fallen into oblivion. I will show how the mathematical logicians' hostility can be understood in light of (i) the Kantian myth that logic had made no progress since Aristotle and (ii) the drastic changes in the relationship between logic and its broader cultural-religious context. By identifying this case of Vergessenmachen, the essay illustrates the need for a more inclusive and integrative historiography of logic.
\end{abstract}

\section{LOGIC AND ITS HISTORY}

Upon looking at the trivium and the quadrivium, which jointly make up the seven classical artes liberales, one immediately notices two disciplines that appear to be 'out of place' or 'misclassified', at least from a modern point of view. First of all, music was traditionally placed among the mathematical sciences (artes reales) of the quadrivium (along with arithmetic, geometry and astronomy), whereas today, music(ology) is associated much more closely with the arts and humanities. Secondly, the discipline of logic (dialectica) was traditionally classified with the linguistic sciences (artes sermocinales) of the trivium (along with grammar and rhetoric), whereas today, logic is often seen as being highly mathematical in nature. This is also clear from the fact that in present-day universities, logic is taught not only in philosophy and arts faculties, but also in mathematics and computer science departments.

This wavering between the linguistic-philosophical outlook of the trivium and the scientificmathematical perspective of the quadrivium has had a profound influence on the history of logic. In this 
essay, I will explore one particular aspect of this historical influence. Broadly speaking, the history of (Western) logic proceeds from its initial steps in Aristotle, over the work of the medieval logicians, to the mathematization of logic toward the end of the nineteenth century. ${ }^{1}$ Today, logic is primarily characterized by its thoroughly interdisciplinary nature, with traditional connections to philosophy and mathematics, but also newly forged links to disciplines such as linguistics, psychology and computer science. Borrowing a term from the sociologist of science Oliver Dimbath, I will argue that the mathematization of logic led to a clear attempt at Vergessenmachen in the historiography of this discipline. ${ }^{2}$ Several pioneers of the mathematical tradition deemed their approach far superior to the Aristotelian (and especially the medieval) tradition in logic. They attempted to push this earlier work into oblivion, by treating it with (often extreme) hostility. I will also show that this process of Vergessenmachen had a profound impact on the subsequent development of logic. After all, due to the above-mentioned processes of scholarly forgetting, certain new steps in logical research-which required bringing together elements from the Aristotelian and mathematical approaches — were taken at a very slow pace, and often only after being instigated or catalyzed by disciplinary outsiders, for whom the earlier Aristotelian tradition had not fallen into oblivion. Finally, I will discuss several explanations for these changes in logicians' attitudes, focusing on the myth (first popularized by Immanuel Kant) that logic had made no real progress since Aristotle, and on the broader cultural-religious context of logic research.

In order to keep this essay relatively self-contained, it might be useful to start by briefly describing the subject matter and history of logic. (The remainder of this section is thus mainly meant for readers without much prior knowledge of logic and its history.) Logic can be viewed as the systematic study of reasoning. In philosophy, in science, but also in daily life, we constantly engage in reasoning, i.e. constructing arguments in which a certain statement (the conclusion) is derived from certain other statements (the premises). The key notion in logic is that of deductive validity, which is defined in terms of truth preservation: an argument is said to be deductively valid if, and only if, whenever all its premises are true, its conclusion has to be true as well. For example, the argument "if it rains, then the streets get wet; it is raining; hence the streets are getting wet" is deductively valid. By contrast, the argument "if it rains, then the streets get wet; the streets are getting wet; hence it is raining" is invalid, because one can easily imagine a situation in which its premises are both true, and yet its conclusion fails to be true (for example, a situation in which it is not raining, but a sewage pipe underneath the streets has burst).

\footnotetext{
${ }^{1}$ Cf. Volker Peckhaus, "19th Century Logic between Philosophy and Mathematics," Bulletin of Symbolic Logic 5, no. 4 (1999): 433-50.

${ }^{2}$ Cf. Oliver Dimbath, "Wissenschaftlicher Oblivionismus. Vom unbewussten zum strategischen Vergessen," in Soziologie des Vergessens. Theoretische Zugänge und empirische Forschungsfelder, ed. Oliver Dimbath and Peter Wehling (Konstanz: Konstanzer Universitätsverlag, 2011), 297-316; id., Oblivionismus: Vergessen und Vergesslichkeit in der modernen Wissenschaft (Konstanz: Konstanzer Universitätsverlag, 2014); Han Lamers, Toon Van Hal and Bas Clercx, "How to Deal with Scholarly Forgetting? Starting points for discussion," History of Humanities \#, no. \# (\#), \# \#.
} 
Any attempt to adequately discuss the history of logic, which encompasses well over two and a half millennia, is bound to be futile. ${ }^{3}$ However, for the specific purposes of this essay, it will be useful to identify three main stages in this history: (i) the Aristotelian origins, (ii) the medieval tradition and (iii) the mathematization of logic.

The first systematic treatment of logic is attributable to Aristotle (384-322 BCE). His logical treatises are the Categories, On Interpretation, the Prior Analytics, the Posterior Analytics, the Topics, and the Sophistical Refutations. Together, these six works later came to be known as the Organon, which shows that logic was considered an 'instrument' (for doing philosophy and science). Aristotle focused on a particular type of argument, viz. the syllogism, which consists of premises and a conclusion that contain a quantifier such as 'all', 'some' or 'no'. A typical example would be: "all Athenians are Greeks; all Greeks are mortal; hence all Athenians are mortal." Over time, Aristotle's logic became so influential that the study of logic became almost synonymous with the study of syllogistics.

A second key phase in the history of logic is found in the late Middle Ages (roughly: 1100-1400). Aristotle's Categories and On Interpretation (translated into Latin by Boethius in the early sixth century), together with a number of commentaries and treatises by Porphyry and Boethius, among others, were known throughout the Middle Ages, and formed the logica vetus. By contrast, the other four works of the Organon (along with the rest of Aristotle's philosophical corpus, and the Arabic commentaries on them) were only rediscovered in the Latin West in the course of the twelfth century, and therefore came to be known as the logica nova. ${ }^{4}$ In general, this period was thus deeply influenced by the Aristotelian logical tradition and its fascination with syllogistics. Key figures from this period include Peter Abelard (1079-1142), Peter of Spain (thirteenth century), William of Sherwood (ca. 12031269), William of Ockham (ca. 1287-1347), John Buridan (ca. 1300-1360) and Albert of Saxony (ca. 1316-1390).

The third crucial period in the history of logic spans from ca. 1850 to 1920 . This period can be described as the mathematization of logic: up until the nineteenth century, logic had been studied almost exclusively by philosophers (recall its traditional place within the trivium), but from the second half of the nineteenth century onwards the discipline started to attract more and more attention from mathematicians as well. Key examples include George Boole (1815-1884), Augustus De Morgan (1806-1871), Charles Sanders Peirce (1839-1914), Gottlob Frege (1848-1925), Alfred North Whitehead (1861-1947), Bertrand Russell (1872-1970) and Ludwig Wittgenstein (1889-1951). Several

\footnotetext{
${ }^{3}$ I will, for example, omit the important traditions of logic research in China and India as well as the Stoic school. For more comprehensive historical overviews, see William Kneale and Martha Kneale, The Development of Logic (Oxford: Clarendon Press, 1962); Leila Haaparanta, ed., The Development of Modern Logic (Oxford: Oxford University Press, 2009); Dov M. Gabbay and John Woods, eds., Handbook of the History of Logic, 11 vols. (Amsterdam, Elsevier, 2004-2014).

${ }^{4}$ Next to the Categories and On Interpretation, Boethius also translated the Prior Analytics, the Topics and the Sophistical Refutations into Latin. However, these latter translations were quickly lost and were rediscovered only in the course of the twelfth century; they thus became part of the logica nova, rather than the logica vetus.
} 
of these authors were appointed as professors in mathematics, and even those that were not had still received a graduate-level mathematical education. Nevertheless, it also bears emphasizing that many of these authors, besides being mathematicians, also were highly influential philosophers. For example, Frege, Russell and Wittgenstein laid the foundations of analytic philosophy, which is currently the dominant approach to philosophy in the Anglo-Saxon world. ${ }^{5}$ These biographical details illustrate that despite its process of mathematization, the discipline of logic did not lose (and has still not lost even today) its original ties with philosophy.

The shift of logic toward mathematics is due to two complementary reasons. First of all, authors such as Boole and De Morgan held that the traditional, Aristotelian system of syllogistics could be studied in a much more precise and systematic way by using the modern language of mathematics (in particular, symbolic algebra). For example, De Morgan pointed out that there exist valid arguments which do not have the formal structure of a syllogism, and thus fall outside the scope of traditional Aristotelian syllogistics. One of his favorite examples involves a genitive construction: " $m a n$ is an animal, therefore the head of a man is the head of an animal' is inference, but not syllogism." ${ }^{\prime 6}$ Considerations such as these showed that mathematics could come to the aid of logic. The second reason for the mathematization of logic involves a process that is internal to mathematics itself. In the course of the nineteenth century, mathematicians had begun to discover all kinds of problems, anomalies and paradoxes in earlier works (e.g., how to conceive precisely of infinitesimally small quantities when dealing with derivatives?). Mathematics, which had always been the most certain and secure of all the sciences, was suddenly shaken in its very foundations. This foundational crisis (Grundlagenkrise) was seen as being due to sloppy and invalid reasoning, which could be solved by gaining a better understanding of arguments and validity, i.e., of logic. Authors such as Frege and Russell therefore believed that logic could provide a new, solid foundation for mathematics, and thus help to overcome the foundational crisis. In other words, here we see logic coming to the aid of mathematics.

This two-way interaction between logic and mathematics is vividly illustrated in Russell and Whitehead's Principia Mathematica, which is perhaps the most important work from this period in the history of logic. After hundreds of pages of meticulous logical reasoning, the authors succeed in providing secure foundations for a fundamental piece of mathematical knowledge: "From this proposition, it will follow, when arithmetical addition has been defined, that $1+1=2 .{ }^{\prime}$ Earlier in the same work, they had already shown that their logical system is able to deal with arguments based on relations (e.g., genitive constructions), and remarked: "The above is the type of inference concerning

\footnotetext{
${ }^{5}$ Cf. Erich H. Reck, ed., From Frege to Wittgenstein: Perspectives on Early Analytic Philosophy (Oxford: Oxford University Press, 2002).

${ }^{6}$ Augustus De Morgan, Formal Logic (London: Taylor and Walton, 1847), 114.

${ }^{7}$ Alfred North Whitehead and Bertrand Russell, Principia Mathematica (Cambridge: Cambridge University Press, 3 volumes, 1910, 1912, 1913), vol. 1, 360 .
} 
which Jevons says: "I remember the late Prof. De Morgan remarking that all Aristotle's logic could not prove that 'Because a horse is an animal, the head of a horse is the head of an animal'."'”

\section{VERGESSENMACHEN IN THE HISTORIOGRAPHY OF LOGIC}

The mathematization of logic had a profound impact on the discipline, ranging from the methods that are used, over the questions that are deemed worthwhile to investigate, to the way in which the subject is taught. If one compares typical pre- and post-mathematization logic textbooks, one might be hardpressed to recognize them as belonging to the same discipline at all. For example, Rosental recently wrote: “Aristotelian logic was the dominant approach to logic for more than 2,000 years until the second half of the twentieth century, when it was nearly completely absent from contemporary logic courses for undergraduates." 9 A similar attitude was already voiced by Williamson in the 1970s: "It may occur to one who suffers traditional logic and later learns something of [mathematical] propositional logic that there is a considerable difference in the methods used in these two branches of what is supposed to be the same discipline." 10 In the early stages of the period of mathematization, the traditional Aristotelian approach to logic co-existed with the newly minted mathematical approach. However, it quickly became evident that both approaches were genuinely competing with each other for dominance in the discipline of logic, a competition that was clearly won by the mathematical approach. Robin Smith characterizes the situation as follows: "During the rise of modern formal logic following Frege and Peirce, adherents of Traditional Logic (seen as the descendant of Aristotelian Logic) and the new mathematical logic tended to see one another as rivals, with incompatible notions of logic."11

Smith's characterization of the Aristotelian and mathematical traditions in logic as "rivals" is actually a severe understatement. ${ }^{12}$ The competition for dominance in logic was won by the mathematical approach, on the one hand because of reasons of substance, such as its broader scope of application (e.g., think of its ability to deal with arguments involving genitive constructions; cf. infra for a qualification in this respect), but on the other hand, also because of other, more ideologically colored reasons. Several pioneers in the mathematical tradition deemed their approach far superior to the earlier, Aristotelian (and especially medieval) tradition in logic, and actively attempted to push this earlier work into

\footnotetext{
${ }^{8}$ Ibid., 306.

9 Creighton Rosental, “Aristotle's "Logical Worldview": Understanding Logic Through Philosophy," in Philosophical Perceptions on Logic and Order, ed. Jeremy Horne (Hershey, PA: IGI Global, 2018), 123-40, 123.

${ }^{10}$ Colwyn Williamson, “Traditional logic as a logic of distribution-values," Logique et Analyse 14, no. 56 (1971): 729-46, 729. Notice the hostility toward traditional logic that shimmers through in Williamson's remarks (cf. the word "suffers"); we will return to this hostility later in this section.

${ }^{11}$ Robin Smith, “Aristotle's Logic,” in Stanford Encyclopedia of Philosophy (Spring 2018 edition), ed. Edward N. Zalta (Stanford, CA: CSLI, 2018), my emphases.

12 This was already clear at an early stage. For example, by 1939, one could conclude that "Recent years have seen bitter warfare between followers of symbolic logic and Aristotelian logic." See Leonard J. Eslick, "Grammatical and Logical Form," New Scholasticism 13, no. 3 (1939): 233-44, 233, my emphasis.
} 
oblivion. In order to achieve this goal, rather than simply ignoring the earlier, Aristotelian tradition and dispassionately pursuing their own research, the mathematical pioneers frequently discussed the earlier tradition with (often extreme) hostility. This conscious effort to bring about a systematic forgetting of this vast body of knowledge (accumulated over the course of two millennia) constitutes a prime example of Oliver Dimbath's notion of Vergessenmachen (cf. footnote 2).

In order to obtain a better sense of the degree of hostility involved, let us take a look at some concrete examples. Already at the very beginning of the period of mathematization in the $1850 \mathrm{~s}$, Augustus De Morgan believed that "[a]ppropriating logic from metaphysicians such as Hamilton was more than a technical necessity [...because...] [t] he consequences of philosophy's stranglehold on logic were grave." ${ }^{13}$ A more vivid illustration is to be found in Ludwig Wittgenstein's first official publication: a book review from 1913, which discusses a book (published in 1912) that firmly belongs to the Aristotelian tradition in logic. Wittgenstein began his review as follows:

In no branch of learning can an author disregard the results of honest research with so much impunity as he can in Philosophy and Logic. To this circumstance we owe the publication of such a book as $\mathrm{Mr}$ Coffey's 'Science of Logic': and only as a typical example of the work of many logicians to-day does this book deserve consideration. The author's Logic is that of the scholastic philosophers, and he makes all their mistakes - of course with the usual references to Aristotle. (Aristotle, whose name is so much taken in vain by our logicians, would turn in his grave if he knew that so many Logicians know no more about logic to-day than he did 2,000 years ago)..$^{14}$

Without a doubt, the most outspoken of the mathematical pioneers was Bertrand Russell. In his monumental History of Western Philosophy, he wrote that Aristotle's logical doctrines "are wholly false, with the exception of the formal theory of the syllogism, which is unimportant. Any person in the present day who wishes to learn logic will be wasting his time if he reads Aristotle or any of his disciples."15 While Russell still showed some appreciation for the originality displayed in Aristotle's own logical works, he absolutely abhorred the tradition that they gave rise to, which he saw as a period of complete uncreativity. For example, he complained "how admirable [Aristotle's] logical work would still seem if it had been a stage in a continual progress, instead of being (as in fact it was) a dead end, followed by over two thousand years of stagnation," 16 and that "[b]y the time that logical originality revived, a reign of two thousand years had made Aristotle very difficult to dethrone. Throughout modern times, practically every advance in science, in logic, or in philosophy has had to be made in the teeth of opposition from Aristotle's disciples."17

\footnotetext{
${ }^{13}$ Daniel J. Cohen, Equations from God: Pure Mathematics and Victorian Faith (Baltimore, MD: Johns Hopkins University Press, 2007), 121, my emphases.

${ }^{14}$ Ludwig Wittgenstein, Philosophical Occasions, 1912-1951 (Indianapolis, IN: Hackett, 1993), 2-3.

${ }^{15}$ Bertrand Russell, The History of Western Philosophy (London: Allen and Unwin, 1946), 225.

${ }^{16}$ Russell, The History, 218.

${ }^{17}$ Russell, The History, 225.
} 
The same kind of hostility continued to reign even when the period of mathematization was reaching its end, and the mathematical approach had almost completely replaced the Aristotelian tradition as the dominant position in logic research. For example, Willard Van Orman Quine, one of the most influential logicians and analytic philosophers of the twentieth century, opened his logic textbook of 1950 by emphasizing that all work prior to the publication of Frege's Begriffsschrift in 1879 is merely a prelude to the great discoveries of the mathematical logicians: "Logic is an old subject, and since 1879 it has been a great one." ${ }_{18}$ Another telling display of this kind of hostility, from the end of the twentieth century, deserves to be quoted in full:

The so-called 'traditional logic' that is still passed dutifully from textbook to textbook is a stone which has rolled so slowly and so far that, by the time it finally came to rest early in this century, it had gathered all sorts of moss, some going all the way back to Aristotle, some added by medieval logicians, and some of very recent acquisition. As a result of this chequered history, it was, from the point of view of anyone interested in logical systems, left in a rather sad state when it was more or less abandoned. [...] I will not try to trace the history which produced the sorry set of doctrines now called 'traditional' or 'syllogistic' logic. ${ }^{19}$

A strategy that was frequently used by the mathematical logicians to push the tradition of Aristotelian logic into oblivion involved drawing a comparison with the field of astronomy. After all, when the likes of Nicolaus Copernicus (1473-1543) and Galileo Galilei (1564-1642) rendered the ancient AristotelianPtolemaic system of astronomy obsolete, and replaced it with a modern, heliocentric conception of the universe, this constituted a crucial step in the Scientific Revolution. Hence, if Aristotelian logic could be portrayed as being of equal scientific merit as Aristotelian astronomy, it would seem entirely justified to view the former as obsolete and ready to slide into oblivion, just like the latter. Furthermore, this analogy naturally suggested a role for the newly developed mathematical logic: just like Copernicus and Galilei had replaced the obsolete Aristotelian astronomy with a new type of astronomy, so too would the mathematical logicians replace the obsolete Aristotelian logic with a new type of logic.

One of the champions of this strategy was Bertrand Russell, who wrote in the 1940s:

In most universities, the beginner in logic is still taught the doctrine of the syllogism, which is useless and complicated, and an obstacle to a sound understanding of logic. If you wish to become a logician, there is one piece of advice which I cannot urge too strongly, and that is: Do NOT learn the traditional formal logic. In Aristotle's day it was a creditable effort, but so was the Ptolemaic astronomy. To teach either in the present day is a ridiculous piece of antiquarianism. ${ }^{20}$

\footnotetext{
${ }^{18}$ Willard V. O. Quine, Methods of Logic (New York, NY: Holt, Rinehart and Winston, 1950), vii. Displaying a refined sense of humor, the Aristotle scholar Jonathan Lear later reformulated Quine's statement as follows: "Logic is an old subject and since the fourth century B.C. it has been a great one"; Jonathan Lear, Aristotle and Logical Theory (Cambridge: Cambridge University Press, 1980), ix.

${ }^{19}$ Colwyn Williamson, "How Many Syllogisms Are There?” History and Philosophy of Logic 9, no. 1 (1988): 77-85, 77.

${ }^{20}$ Bertrand Russell, The Art of Philosophizing and Other Essays (New York, NY: Philosophical Library, 1968), 38.
} 
Elsewhere, Russell proclaimed: "Even at the present day, all Catholic teachers of philosophy and many others still obstinately reject the discoveries of modern logic, and adhere with a strange tenacity to a system which is as definitely antiquated as Ptolemaic astronomy"21; similar sentiments can be discerned in the following quotation: "Ever since the beginning of the seventeenth century, almost every serious intellectual advance has had to begin with an attack on some Aristotelian doctrine; in logic, this is still true at the present day." 22 An even more extreme version of this strategy was used by Wittgenstein in his 1913 book review (cf. supra): "The author has not taken the slightest notice of the great work of the modern mathematical logicians - work which has brought about an advance in Logic comparable only to that which made Astronomy out of Astrology, and Chemistry out of Alchemy." ${ }^{23}$

Just like the general atmosphere of hostility toward Aristotelian logic, this particular strategy of Vergessenmachen persisted even after the period of mathematization, especially in the rapidly developing secondary literature on Frege. For example, in a 1980 monograph we read: "By terminating the life span of Aristotle's [logical] system Frege completed a process that had begun centuries earlier with Galileo's destruction of Aristotelian physics." ${ }^{24}$ The same analogy is also drawn in a book from 2012: "In its efforts to preserve the Aristotelian thesis of an earth at rest in the center of the cosmos, the Ptolemaic system had become an intractable tangle of epicycles. So it was with Aristotelian logic. [...] But when it comes to the revolution in logic, it is the mathematician Gottlob Frege who played the role of Copernicus.”25

To conclude this section, I want to address two more general issues. First of all, as is already suggested by terminology such as "rivals" and "bitter warfare" (cf. footnotes 11-12), hostility was found on both sides of the dispute. Mathematical authors considered their approach to logic far superior to that of the Aristotelian tradition, but simultaneously, the traditional logicians often treated mathematical logic with contempt, and tried to dismiss it as futile or even destructive. ${ }^{26}$ While I agree with this characterization, it is nevertheless my general impression (as illustrated above) that the hostility displayed by the mathematical logicians toward traditional logic was far more frequent, and often also far more extreme in its belligerence, than that displayed by the traditional logicians toward mathematical logic. Furthermore, we have also seen that the mathematicians' hostility continued to reign until long after the dispute had clearly been settled in their favor. While one can reasonably expect severe hostilities

\footnotetext{
${ }^{21}$ Russell, The History, 218.

${ }^{22}$ Russell, The History, 182.

${ }^{23}$ Wittgenstein, Philosophical Occasions, 3.

${ }^{24}$ Hans D. Sluga, Gottlob Frege (London: Routledge, 1980), 65.

${ }^{25}$ Gregory Landini, Frege's Notations: What They Are and How They Mean (London: Palgrave Macmillan, 2012$), 1$.

${ }^{26}$ Many concrete illustrations of the traditional logicians' dismissive attitude can be found in Dany Jaspers and Pieter A. M. Seuren, "The Square of Opposition in Catholic Hands. A Chapter in the History of the $20^{\text {th }}$-Century Logic," Logique et Analyse 59, no 233 (2016): 1-35.
} 
during a paradigm shift, it is less clear why they should continue afterwards, when the new paradigm has been firmly installed.

Secondly, one could object that the mathematical logicians' hostility does not necessarily amount to a genuine case of Vergessenmachen. After all, by attacking something in order to erase it from memory, one is simultaneously highlighting it and thereby making it harder to forget. ${ }^{27}$ In a paradoxical twist, hostility thus almost seems to be incompatible with Vergessenmachen, rather than being a means to achieve it. At first sight, this paradox indeed seems to apply to the hostile remarks that we have discussed above: by vehemently attacking traditional logic, the mathematical logicians might actually have saved this tradition from oblivion, rather than pushing it into it. However, it should be kept in mind that the mathematical logicians often made these hostile remarks with the ultimate goal of getting traditional logic banned from being taught at universities, in order to be replaced with modern, mathematical logic. This goal, if successfully achieved, would imply that new generations of students no longer learn about traditional logic, and would thus effectively amount to (a step toward) genuine Vergessenmachen. If the mathematical logicians were aware of the seemingly paradoxical nature of their hostility toward traditional logic, they might plausibly have viewed it as a necessary intermediate step toward achieving their ultimate goal-like a ladder that one can throw away after having climbed it, to borrow a Wittgensteinian metaphor.

\section{VERGESSENMACHEN AND ITS IMPACT ON LOGIC RESEARCH}

The processes of scholarly oblivion and hostility that occurred during the mathematization of logic had far-reaching consequences for the subsequent development of logic. There exist many topics that can be fruitfully studied using the modern tools and techniques of mathematical logic (several concrete examples will be discussed later). However, because these topics have traditionally been associated with the Aristotelian (and especially, the medieval) tradition in logic, mathematical logicians have for a long time rejected them out of hand, deeming them old-fashioned, misguided, and unworthy of serious mathematical investigation. Many of these topics ultimately ended up being studied using mathematical techniques after all, ${ }^{28}$ but often only after being instigated or catalyzed by disciplinary outsiders. ${ }^{29}$ After all, the practitioners of other disciplines were not (or at least: less severely) influenced by the process of Vergessenmachen that had been ravaging in the discipline of logic itself. For example, the philosopher

\footnotetext{
${ }^{27}$ Cf. Aleida Assmann, Formen des Vergessens (Göttingen: Wallstein Verlag, 2016).

${ }^{28}$ For example, regarding the logical theories of Aristotle himself, Robin Smith has noted that "[m]ore recent scholarship has often applied the very techniques of mathematical logic to Aristotle's theories, revealing (in the opinion of many) a number of similarities of approach and interest between Aristotle and modern logicians," Smith, AL.

${ }^{29}$ An exception in this regard is the Lwów-Warsaw school in logic, whose members already fruitfully combined Aristotelian and mathematical logic in the first half of the twentieth century; cf. footnote 67 for a possible explanation.
} 
Philip Peterson (1943-2001), who often collaborated with linguists, began his most influential book as follows:

Some "modern logicians" have manifested an almost religious zeal in trying to quash anything in logic research which favors the traditional syllogism and/or departs from now orthodox methods [...] I have found their hostility $[\ldots]$ truly remarkable, especially in its incompetence and irresponsibility about the actual facts of the syllogism. [...] I do hope [this book] will help future students to be both more openminded logically (and philosophically too) and more competent in the history of logic as well as in contemporary linguistics. ${ }^{30}$

I will now describe some concrete examples of the general scenario that was laid out above. During ancient and medieval times, logic was inherently interdisciplinary in nature, with connections to disciplines such as metaphysics, epistemology, linguistics, etc. (This should already be clear from the Aristotelian term 'Organon': logic was viewed as an instrument for doing science and philosophy.) For example, one might wish to reason about metaphysical notions such as modality and time, or about epistemological notions such as such as knowledge and belief. During the late Middle Ages, this gave rise to the development of sophisticated systems of modal logic, temporal logic, epistemic logic, etc. ${ }^{31}$ Furthermore, medieval logicians paid great attention to the peculiarities of natural language and the valid argument patterns that they give rise to, and they even attempted to construct a technical logical language through the regimentation of Latin. ${ }^{32}$ All of this changed drastically during the period of mathematization. Logical issues concerning metaphysical and epistemological notions such as modality, time, knowledge and belief were largely ignored, partially because they do not bear a direct connection to the project of mathematical foundations, but at least partially also because of their association with traditional (Aristotelian) logic — recall, for example, Augustus De Morgan's concerns regarding the grave "consequences of philosophy's stranglehold on logic" (cf. footnote 13). Furthermore, early mathematical logicians were not particularly interested in natural language, which they primarily viewed as a deceiving distortion of an ideal (mathematical) language. ${ }^{33}$

Only in the second half of the twentieth century, when the most extreme displays of hostility had started to fade away, mathematical logicians began to realize that they could apply their freshly minted

\footnotetext{
${ }^{30}$ Philip L. Peterson, Intermediate Quantifiers: Logic, Linguistics, and Aristotelian Semantics (Aldershot: Ashgate, 2000), iii.

${ }^{31}$ Simo Knuuttila, Modalities in Medieval Philosophy (London: Routledge, 1993); Ivan Boh, Epistemic Logic in the Later Middle Ages (London: Routledge, 1993).

${ }^{32}$ Cf. Stephen Read, "Non-Normal Propositions in Buridan's Logic," in Formal Approaches and Natural Language in Medieval Logic, ed. Laurent Césalli, Frédéric Goubier and Alain de Libera (Turnhout: Brepols, 2017), 453-68.

${ }^{33}$ The historian of medieval philosophy Alain de Libera has summarized the situation as follows: "A une époque où dominait le modèle de logiques formelles de type mathématique, la visée linguistique ou logico-linguistique des doctrines médiévales ne pouvait apparaitre que comme un handicap. Le renouvellement de la problématique de la logique naturelle qu'a entraîné en linguistique le développement des points de vue sémantiques génératif et interprétatif permet aujourd'hui de mieux apprécier les réussites et les limites de la "logique du Latin" qu'ont élaborée les philosophes des XIII et XIVe siècles." Alain de Libera, "La logique du moyen âge comme logique naturelle (Sprachlogik)," in Sprachphilosophie in Antike und Mittelalter, ed. Burkhard Mojsisch (Amsterdam: Verlag B. R. Grüner, 1986), 403-37, 403. Also cf. Gyula Klima, "Natural Logic, Medieval Logic and Formal Semantics,” Magyar Filozófiai Szemle 54, no. 4 (2010): 58-75.
} 
tools and techniques not only to the foundations of mathematics, but also, and equally fruitfully, to the kinds of metaphysical, epistemological and linguistic issues that had largely been ignored until then. This gave rise to the mathematical development of frameworks such as temporal logic, epistemic logic, generalized quantifier theory, etc. ${ }^{34}$ The interface between traditional and mathematical logic was no longer viewed in terms of opposition and hostility, but rather in terms of cooperation and crossfertilization. For example, by the late 1980s, Dag Westerståhl ( $\left.{ }^{\circ} 1946\right)$ could discuss his mathematical work on generalized quantifiers in light of the earlier, Aristotelian tradition in logic. Interestingly, Westerståhl mentions the infamous analogy with Aristotelian-Ptolemaic astronomy, but unlike many of his mathematical predecessors, he explicitly dismisses it as mistaken:

The step from Aristotelian physics to Galilean physics is nowadays a prime textbook example of a 'paradigm shift' in science [...]. Could something similar, albeit on a smaller scale, be said of the step in the late 19th century from Aristotelian to modern logic? A quick look at some of the writings of Frege and Russell, or of textbook accounts of the birth of modern logic, would seem to indicate this. In the present note I wish to point out, however, that such an impression is mistaken. [...] It can in fact be seen that (i) there is no principled opposition between [modern] predicate logic and [Aristotelian] adherence to subject-predicate form, (ii) Aristotle's treatment of quantification fits quite well into (one direction of) a modern study of generalized quantifiers. ${ }^{35}$

Two aspects of this story bear emphasizing. First of all, it is probably no coincidence that many of its protagonists not only worked on mathematical logic, but also on the history of (traditional) logic. For example, Arthur N. Prior (1914-1969) and Jaakko Hintikka (1929-2015) were the founding fathers of resp. temporal logic and epistemic logic (cf. footnote 34), but they also did important historical work on resp. medieval logic and Aristotle's logic. ${ }^{36}$ This shows that one cannot always easily distinguish between a given scientific discipline and the historiography of that discipline, especially for relatively small and specialized fields such as logic. Secondly, many of the developments mentioned above were crucially instigated or catalyzed by research outside the disciplinary boundaries of mathematical logic. For example, much important work in temporal logic and epistemic logic has been inspired by considerations from artificial intelligence, ${ }^{37}$ while the most seminal paper on generalized quantifier

\footnotetext{
${ }^{34}$ Arthur N. Prior, Time and Modality (Oxford: Clarendon Press, 1957); id., Past, Present and Future (Oxford: Clarendon Press, 1967); Jaakko Hintikka, Knowledge and Belief. An Introduction to the Logic of the Two Notions (Ithaca, NY: Cornell University Press, 1962); Jon Barwise and Robin Cooper, "Generalized Quantifiers and Natural Language," Linguistics and Philosophy 4, no. 2 (1981): 159-219.

${ }^{35}$ Dag Westerståhl, “Aristotelian Syllogisms and Generalized Quantifiers,” Studia Logica 48, no. 4 (1989): 577-85, 577-8, my emphases.

${ }^{36}$ Sara Uckelman, "Arthur Prior and Medieval Logic," Synthese 188, no. 3 (2012): 349-66; Jaakko Hintikka, Analyses of Aristotle (Berlin: Springer, 2004).

${ }^{37}$ Peter Øhrstrøm and Per Hasle, Temporal Logic: From Ancient Ideas to Artificial Intelligence (Berlin: Springer, 1995); JohnJules Ch. Meyer and Wiebe van der Hoek, Epistemic Logic for AI and Computer Science (Cambridge: Cambridge University Press, 1995); Lorenz Demey, "De dynamische wending in de epistemische logica," Tijdschrift voor Filosofie 78, no. 2 (2016): $365-91$.
} 
theory (cf. footnote 34) is the result of a cooperation between the logician Jon Barwise (1942-2000) and the linguist Robin Cooper $\left({ }^{\circ} 1947\right)$.

For a final example of the nefarious impact of the attempted Vergessenmachen, one might consider the so-called 'square of opposition', which is a visual representation of certain statements and the logical relations holding between them. These relations were already studied by Aristotle himself. The square itself is due to Apuleius (ca. 125-175), Ammonius (ca. 440-520) and Boethius (ca. 475-525); it became extremely popular in medieval logic, and continued to be studied well into the nineteenth century; cf. Figure 1 for an example. However, during the mathematization of logic, the square of opposition quickly lost its popularity, ${ }^{38}$ which is most probably due to its association with traditional logic.

An alternative explanation for the square's declining popularity might be that, unlike traditional syllogistics, modern first-order logic admits the empty set in its models, which renders the logical relations visualized by the square of opposition invalid. However, this explanation fails to take into account that many mathematical logicians subscribed to the "Principle of Tolerance": as long as one is sufficiently careful, one is completely free to construct and study alternative logical systems. ${ }^{39}$ Just like there is no genuine conflict between Euclidean and non-Euclidean systems of geometry, these mathematical logicians argued, there is no genuine conflict between different systems of mathematical logic, e.g. classical Boolean logic (which obeys the law of excluded middle) and intuitionistic logic (which does not obey the law of excluded middle). In exactly the same fashion, one can also argue that there is no genuine conflict between first-order logic (which admits the empty set in its models) and traditional syllogistics (which does not admit the empty set). In other words: the Principle of Tolerance entails that there are no strictly logical grounds for abandoning the square of opposition. The most plausible explanation for the square's declining popularity thus continues to be a more ideological one, which views the square of opposition (and traditional logic in general) primarily as the object of the mathematical logicians' attempted Vergessenmachen.

While the square of opposition was rapidly losing its popularity among mathematical logicians, it continued to be used by linguists, computer scientists, psychologists and many other scientists. ${ }^{40}$ Based on this wide range of interdisciplinary applications, the square of opposition - and many larger, more complex diagrams - has been able to attract the renewed interest of logicians. It turns out that despite their origins in traditional (Aristotelian) logic, these diagrams can be fruitfully studied as objects of

\footnotetext{
${ }^{38}$ A noteworthy exception is that Frege included a mathematized version of the square in his Begriffsschrift (1879).

${ }^{39}$ Rudolf Carnap, The Logical Syntax of Language (London: Routledge \& Kegan Paul, 1937), 51-2.

${ }^{40}$ To give just one example: the article by Westerståhl mentioned in footnote 35 contains a square of opposition. The references mentioned in footnote 41 contain many more examples of interdisciplinary uses of the square of opposition.
} 
independent mathematical interest. These systematic investigations have led to the burgeoning subfield of logical geometry. ${ }^{41}$

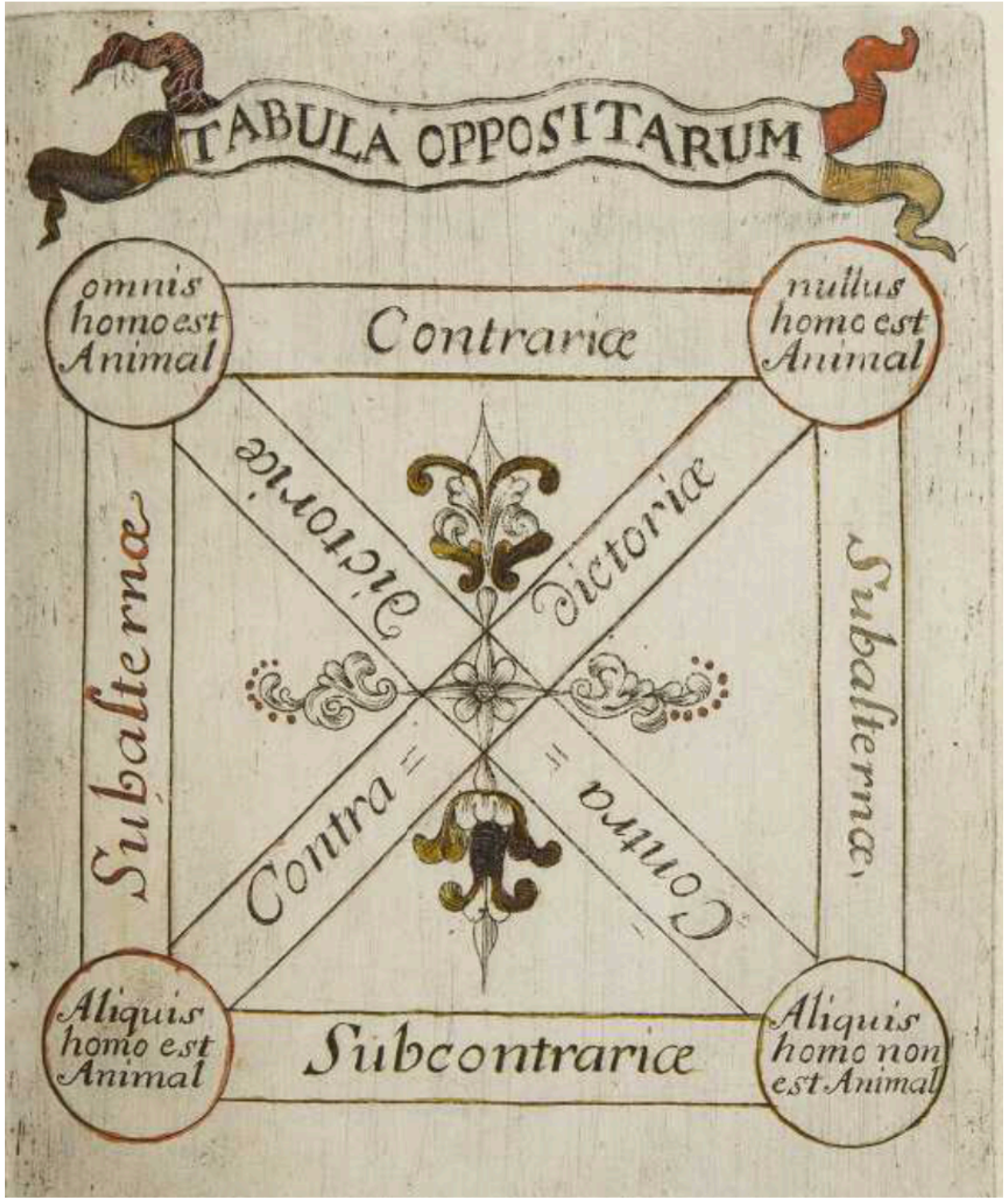

Figure 1: Hand-drawn and richly decorated square of opposition (tabula oppositarum), as found in a student notebook for a logic course at the University of Leuven, 1698-1699. Archives de l'Université catholique de Louvain, Louvain-la-Neuve, Ms. C24, f70r.

\footnotetext{
${ }^{41}$ Cf. Lorenz Demey, "Computing the Maximal Boolean Complexity of Families of Aristotelian Diagrams," Journal of Logic and Computation 28, no. 6 (2018), 1323-39; Lorenz Demey and Hans Smessaert, "Combinatorial Bitstring Semantics for Arbitrary Logical Fragments," Journal of Philosophical Logic 47, no. 2 (2018), 325-63; Hans Smessaert and Lorenz Demey, "Logical Geometries and Information in the Square of Oppositions," Journal of Logic, Language and Information 23, no. 4 (2014), 527-65.
} 


\section{TOWARD AN EXPLANATION FOR THE VERGESSENMACHEN IN LOGIC}

We have encountered several concrete examples of how the pioneers of the new, mathematical approach in logic actively attempted to push the earlier, Aristotelian (and especially medieval) tradition into oblivion, by treating it with (often extreme) hostility. I would now like to consider some possible explanations for this hostility. Why did many of the early mathematical logicians feel the need to severely berate, criticize, and ridicule the work of their predecessors and even of their contemporaneous colleagues? Why did they not decide to focus on dispassionately pursuing their own mathematical research on logic, so that afterwards, the advantages and disadvantages of the older Aristotelian tradition could be compared with those of the new, mathematical approach, leading to a fair assessment of both?

One possible explanation involves the disciplinary shift that logic underwent during the period of mathematization. Throughout its entire history, the discipline of logic had been very closely associated with philosophy. Logic was used to study philosophical problems, logical innovations were often driven by new philosophical applications, and logic was studied and taught almost exclusively by philosophers. All of this changed drastically during the period of mathematization: logic was now studied in a much more mathematical fashion, and the primary applications of logic also shifted to mathematics. Although there have been many philosophers who were also successful mathematicians (the most well-known example undoubtedly being René Descartes, 1596-1650), philosophy and mathematics essentially remain two distinct disciplines, each with its own goals, topics, methods and applications. When logic shifted from philosophy toward mathematics, it should thus not surprise us that the mathematical logicians wanted to use it for their own, mathematical purposes, and were not particularly interested in the philosophical questions and methods that characterized the earlier, Aristotelian tradition in logic.

This explanation is misguided, however, because it mischaracterizes the actual facts. First of all, this account would more probably have led to an attitude of indifference, rather than to the grave hostility that actually occurred. Secondly, and more importantly, this explanation ignores the fact that many of the protagonists of the mathematization of logic were not only mathematicians, but also philosophers. For example, we have already seen that Frege, Russell and Wittgenstein were among the founding fathers of analytic philosophy. They might have disagreed with the specific answers that their predecessors gave to certain philosophical questions, but at the very least, they were interested in those questions and deemed them worthy of investigation. Accordingly, when someone like Bertrand Russell considered mathematical logic to be superior to traditional Aristotelian logic, he took this superiority to be relevant not only for mathematics, but also for philosophy: "Logic is useful to the philosopher in its modern form, not in the musty medieval form that the schoolmen produced out of Aristotle." ${ }^{42}$

\footnotetext{
${ }^{42}$ Russell, The Art, 8, my emphasis. Another, more recent expression of the same idea is attributable to Jonathan Lear: "Owing to the tremendous advances in logic since Frege's publication of the Begriffsschrift in 1879, philosophers have tended to ignore Aristotle's logic. They believe that Aristotle's syllogistic is a trivial logical system of little philosophical use." Lear, Aristotle, ix, my emphases.
} 
In order to truly understand the origins of the mathematical logicians' hostility toward the earlier Aristotelian tradition in logic, we will thus have to dig deeper into the historiography of logic. In particular, I would like to consider the crucial role of the myth that logic had made no real progress since Aristotle. Several mathematical logicians explicitly appealed to this myth in some of their most hostile passages. For example, we already encountered Russell's claim that Aristotle's works on logic were "followed by over two thousand years of stagnation,"43 as well as Wittgenstein's complaint that Aristotle "would turn in his grave if he knew that so many Logicians know no more about logic to-day than he did 2,000 years ago." ${ }^{44}$ In a 1950 textbook on mathematical logic, we read that "using mathematical methods $[\ldots]$ has led to more knowledge about logic in one century than had been obtained from the death of Aristotle up to 1847, when Boole's masterpiece was published." ${ }^{45}$ Similar ideas continue to dominate today. For example, Gasser writes that "[c]enturies of stagnation in the study of logic were followed by an explosion of progress in the late nineteenth century," ${ }^{46}$ while Sluga maintains that "PostAristotelian logic begins only with Frege." ${ }^{47}$

The idea that logic had not made any substantial progress after Aristotle did not originate during the period of mathematization, however. It can be traced back much earlier, viz. to the great German philosopher Immanuel Kant (1724-1804). ${ }^{48}$ In the preface to the second edition of his magnum opus, the Critique of Pure Reason (Kritik der Reinen Vernunft), Kant wrote:

That from the earliest times logic has traveled this secure course can be seen from the fact that since the time of Aristotle it has not had to go a single step backwards [...] What is further remarkable about logic is that until now it has also been unable to take a single step forward, and therefore seems to all appearance to be finished and complete. ${ }^{49}$

Kant's assessment inspired the nineteenth-century historian of logic Carl Prantl (1820-1888) to conclude "that any logician after Aristotle who said anything new was confused, stupid, or perverse." ${ }_{50}$ When mathematical authors such as Russell and Wittgenstein proclaimed that logic had made no

\footnotetext{
${ }^{43}$ Russell, The History, 218, my emphasis.

${ }^{44}$ Wittgenstein, Philosophical Occasions, 3, my emphasis.

${ }^{45}$ Paul C. Rosenbloom, The Elements of Mathematical Logic (New York, NY: Dover Publications, 1950), i.

${ }^{46}$ James Gasser, A Boole Anthology: Recent and Classical Studies in the Logic of George Boole (Dordrecht: Kluwer, 2000), vii, my emphasis.

${ }^{47}$ Sluga, Gottlob Frege, 65.

${ }^{48}$ In fact, a general negative attitude vis-à-vis medieval logic was already clearly present in the works of humanist authors such as Lorenzo Valla (1406-1457) and Juan Luis Vives (1493-1540). Cf. Rita Guerlac, Juan Luis Vives Against the Pseudodialecticians: A Humanist Attack on Medieval Logic (Dordrecht: Reidel, 1979).

${ }^{49}$ Immanuel Kant, Critique of Pure Reason, translated by Paul Guyer and Allen W. Wood (Cambridge: Cambridge University Press, 1998), 106, my emphasis.

${ }^{50}$ Smith, AL. Prantl's main work on the history of logic is his Geschichte der Logik im Abendlande (Leipzig: S. Hirzel, 4 volumes, 1855, 1861, 1867, 1870). Although Prantl's Geschichte was absolutely the standard reference on the history of logic in the first decades after its appearance, by the 1950s it was widely regarded as erroneous and misguided in nearly every aspect. It should not be surprising that this evaluative shift coincides precisely with the mathematization of logic, since the latter also implies that "no trustworthy conception of the history of logic was possible until modern and mathematical logic provided a precise criterion for formal logic.” Otto Bird, “The History of Logic,” Review of Metaphysics 16, no. 3 (1963): 491-502, 492.
} 
substantial progress since Aristotle, they were in a sense merely repeating the words of Kant and Prantl. Of course, the mathematical logicians wholeheartedly disagreed with the final part of Kant's assessment, according to which logic is "finished and complete", but to the extent that they wanted to emphasize the centuries of stagnation after Aristotle, they could simply invoke the philosophical authority of Kant.

The natural questions to ask now are thus: why did Kant think that the discipline of logic had not been able to take a single step forward since Aristotle? On the basis of what historical facts did he reach this conclusion? And was his conclusion justified, i.e. did logic indeed not make any substantial progress after Aristotle? In order to answer these questions, we should consider the particular fashion in which logical (and more generally, philosophical and scientific) research was carried out during the Middle Ages.

In the Middle Ages, and especially from the thirteenth century onwards, Aristotle was seen as the single greatest authority on logic. A significant part of logical research, therefore, took the form of commentaries on the original logical works of Aristotle. ${ }^{51}$ From a contemporary perspective, it is clear that medieval logicians such as Peter of Spain and John Buridan did make highly significant contributions to logic. Typical examples include the medieval theories of suppositio, obligationes, insolubilia, and consequentiae, which simply do not have any direct counterparts in Aristotle's original works. ${ }^{52}$ Another interesting example concerns arguments based on a genitive construction, such as 'man is animal, therefore the head of a man is the head of an animal', which were mentioned by authors such as De Morgan, Russell and Whitehead as problem cases for traditional Aristotelian logic (cf. supra). While it is true that Aristotle's own version of syllogistics could not deal with such arguments, later medieval systems of logic (e.g., that of John Buridan's) are effectively capable of handling them. ${ }^{53}$ In conclusion, it is thus clearly incorrect that logic had not taken a single step forward since Aristotle. This viewpoint, which was first expressed by Kant and later voraciously taken over by the mathematical logicians, is nothing more than a myth. It has no basis in historical fact.

This conclusion should be nuanced, however. Despite the actual originality of their work, the medieval logicians themselves often did not consider their contributions to be highly original or innovative, but merely saw them as modest attempts to explain the finer details in the authoritative texts of Aristotle. Authors such as William of Ockham were highly capable logicians, but because they were active in a pedagogical system that discouraged 'subjective' philosophizing and viewed it as hubris, ${ }^{54}$

\footnotetext{
${ }^{51}$ Cf. Charles Burnett, ed., Glosses and Commentaries on Aristotelian Logical Texts: The Syriac, Arabic and Medieval Latin Traditions (London: Warburg Institute, 1993); H. A. G. Braakhuis and C. H. Kneepkens, eds., Aristotle's Peri Hermeneias in the Latin Middle Ages: Essays on the Commentary Tradition (Groningen-Haren: Ingenium, 2003).

${ }^{52}$ Cf. Catarina Dutilh Novaes and Stephen Read, eds., The Cambridge Companion to Medieval Logic (Cambridge: Cambridge University Press, 2016).

${ }^{53}$ Cf. Stephen Read, “The Medieval Theory of Consequence,” Synthese 187, no. 3 (2012): 899-912.

${ }^{54}$ Cf. Paul R. Blum, Studies on Early Modern Aristotelianism (Leiden \& Boston: Brill, 2012), especially the first chapter:

"Philosophers' Philosophy and School Philosophy".
} 
they often presented their original logical theories in commentaries on Aristotle. The historian of medieval logic Sten Ebbesen has described this as follows: "Thirteenth-century logicians seem to have been blissfully oblivious of their own original contributions to logic," and consequently, "even the most important innovations in scholastic logic were not considered by anyone [in the thirteenth century] as breaking new ground, but only as a technically more advanced tilling of the field already acquired for logic by Aristotle." ${ }^{55}$ This state of affairs made it very easy for an Enlightenment author such as Kant, for whom originality and independence were the hallmarks of scientific excellence, to view medieval logic as nothing more than a period of stagnation. As we have already seen, mathematical logicians such as Russell and Wittgenstein would later attack the medieval tradition of Aristotelian logic for exactly the same reason.

\section{A BROADER LOOK: LOGIC AND THE CHURCH}

I now turn to a final element that might help to explain the severe hostility between the mathematical and the Aristotelian (especially medieval) traditions in logic, viz. the broader cultural context of logic research, and in particular, the changing relation between logic and the church. In the Latin Middle Ages, logic (and nearly all other serious intellectual activities as well) developed in a deeply Christian context. Many logicians went on to become theologians: they started their university careers at the Faculty of Arts, and subsequently moved on to the Faculty of Theology. ${ }^{56}$ In order to finance their theological studies, they taught logic at the Faculty of Arts. Hence, important medieval logicians such as Peter Abelard and William of Ockham also produced treatises on theological topics (e.g., the Eucharist) and biblical commentaries (e.g., on Paul's Epistle to the Romans). This religious context remained in place long after the Middle Ages. For example, some of the most important logicians of the sixteenth and seventeenth centuries were the Dominicans from the School of Salamanca and the Jesuit Conimbricenses, including authors such as Domingo de Soto (1494-1560), Domingo Báñez (15281604) and Pedro da Fonseca (1528-1599).

This stands in sharp contrast to the early mathematical logicians, many of whom were staunchly antireligious. This is perhaps clearest in the case of Bertrand Russell, who is famous for his essay "Why I

\footnotetext{
${ }^{55}$ Sten Ebbesen, "What Counted as Logic in the Thirteenth Century?" in Methods and Methodologies: Aristotelian Logic East and West, 500-1500, ed. Margaret Cameron and John Marenbon (Leiden \& Boston: Brill, 2011), 93-107, resp. 99, 105. This situation was by no means restricted to the thirteenth century, or to the Latin world. "In the Greek as well as in the Latin world there was no choice at any time in the Middle Ages between Aristotelian and non-Aristotelian logic. New branches of logic could develop, but however un-Aristotelian they might be to an impartial observer, the medievals themselves considered them supplements to Aristotle's logic, not competing theories." Sten Ebbesen, "Western and Byzantine Approaches to Logic," Cahiers de l'Institut du Moyen-Âge Grec et Latin 62 (1992): 167-178, 167. Similarly: "Some medieval authors, such as William of Ockham in the fourteenth century, or Avicenna, in the eleventh century, did bring important logical novelties one could characterize as "extra-Aristotelian" or even "non-Aristotelian". But they were never historically formulated in such a way," Julie Brumberg-Chaumont, "Universal Logic and Aristotelian Logic: Formality and Essence of Logic," Logica Universalis 9 , no. 2 (2015): 253-79, 253.

${ }^{56}$ A notable exception in this regard is John Buridan, who remained at the Faculty of Arts throughout his life.
} 
am not a Christian", but who also criticized religion in many other writings. Outside the purely academic sphere, Russell "argued the case against religion in public debates with eminent theologians and took delight in making anti-religious jibes." ${ }^{57}$ It should thus come as no surprise that when he criticized traditional Aristotelian logic, Russell specifically targeted "all Catholic teachers of philosophy [...who...] still obstinately reject the discoveries of modern logic," ${ }_{58}$ nor that he emphasized that "[t]o this day, teachers in Catholic educational institutions are not allowed to admit that [Aristotelian] logic has defects, and any non-Catholic who criticizes it incurs the bitter hostility of the Roman Church." ${ }^{99}$ In this context it also bears emphasizing that the book that was the subject of Wittgenstein's scathing book review from 1913, was written by an Irish Catholic, who explicitly dedicated it to "his Eminence, Cardinal Mercier, Archbishop of Mechlin." ${ }^{60}$ A final illustration is found in an interview with the mathematical logician and analytic philosopher Alfred J. Ayer (1910-1989), who "always said that religion was absolute verbiage ... if it offends people to call religion nonsensical, let's call it false. I've become much milder in my old age." ${ }^{1}$

Another telling episode in the complex relationship between logic and the church in the Middle Ages concerns the Paris and Oxford condemnations of 1277. The churchmen Stephen Tempier (1210-1279, bishop of Paris) and Robert Kilwardby (1215-1279, archbishop of Canterbury) composed long lists of 'erroneous' propositions which, on Church authority, could no longer be taught or publicly discussed at the universities of Paris and Oxford. ${ }^{62}$ These lists contained several propositions that are concerned with the scope of logic (with respect to theological matters), ${ }^{63}$ or with specific logical issues (such as the definition of contraries, future contingents, and existential import). ${ }^{64}$ Edward Grant and others have extensively illustrated the various ways in which the 1277 condemnations led to major innovations in natural philosophy and science (e.g., the growing importance of counterfactual 'thought experiments'). ${ }^{65}$ However, it is generally agreed that ultimately, these condemnations did not have as profound an impact on the course of logic as they did on the course of natural philosophy. ${ }^{66}$ Nevertheless, the mere suggestion that logical theorizing, with respect to either its scope or its subject matter, should have to

\footnotetext{
${ }^{57}$ Louis Greenspan and Stefan Andersson, eds., Russell on Religion (London: Routledge, 1999), 2. The essay "Why I Am Not a Christian" can be found on p. 77-91 of this book.

${ }^{58}$ Russell, The History, 218.

${ }^{59}$ Russell, The Art, 37-8.

${ }^{60}$ Peter Coffey, The Science of Logic (London: Longmans, Green and Co., 1912), iii.

${ }^{61}$ Ted Honderich, “An Interview with A. J. Ayer,” Royal Institute of Philosophy Supplement 30 (1991): 209-26, 214-5.

${ }^{62}$ Henricus Denifle and Aemilio Chatelain, eds., Chartularium Universitatis Parisiensis, Tomus I (Paris: Delalain, 1889); cf. 543-58 for the list of propositions condemned in Paris, and 558-60 for the Oxford list.

${ }^{63}$ Cf. Sara Uckelman, "Logic and the Condemnations of 1277," Journal of Philosophical Logic 39, no. 2 (2010): 201-27.

${ }^{64}$ Cf. Osmund Lewry, "The Oxford Condemnations of 1277 in Grammar and Logic," in English Logic and Semantics, ed. H. A. G. Braakhuis, C. H. Kneepkens and L. M. de Rijk (Nijmegen: Ingenium, 1981), 235-78; Andrea Tabarroni, "The 10th Thesis in Logic Condemned at Oxford in 1277," in Aristotle's Peri Hermeneias in the Latin Middle Ages: Essays on the Commentary Tradition, ed. H. A. G Braakhuis and C. H. Kneepkens (Groningen-Haren: Ingenium, 2003), 339-61.

${ }^{65}$ Cf. Edward Grant, "The Condemnation of 1277, God's Absolute Power, and Physical Thought in the Late Middle Ages," Viator 10 (1979): 211-44.

${ }^{66}$ Cf. Uckelman, op. cit., 224, for more details.
} 
'obey' religious and theological considerations seems rather outlandish from a contemporary perspective, and would certainly have seemed so from the staunchly anti-religious perspective of many mathematical logicians around the turn of the twentieth century. ${ }^{67}$

\section{CONCLUDING THOUGHTS}

In this essay, I have argued that the mathematization of logic led to a clear case of Vergessenmachen. This took on the form of frequent displays of severe hostility, which one would not expect in a cerebral discipline such as logic, and it also had far-reaching consequences for the further development of logic. However, I have argued that this hostility should be understood in light of (i) the Kantian myth that logic had made no progress since Aristotle and (ii) the drastic changes in the relationship between logic and its broader cultural-religious context.

Recent years have witnessed a rapidly growing body of historical literature on the period of mathematization in logic. However, most of these studies focus exclusively on the 'internal' relations among different mathematical logicians (rather than the 'external' relations with their Aristotelian predecessors), and continue to view mathematical logic as the real starting point of logic. In doing so, they (perhaps unconsciously) re-affirm the biases and prejudices of the mathematical logicians that they study ${ }^{68}$ With this essay, I hope to have shown the need for, as well as the intellectual benefits to be gained from, a more inclusive and integrative historiography of logic.

\section{ACKNOWLEDGMENTS}

An earlier version of this essay was presented at the workshop "Forgetting in the History of Scholarship" (Helmstedt, April 19-21, 2018). The author would like to thank the audience of that workshop, as well as Han Lamers, Christophe Geudens, Hans Smessaert, Margaux Smets, Toon Van Hal, and an anonymous reviewer for their extensive feedback. His research is supported through a postdoctoral fellowship from the Research Foundation-Flanders (FWO) and a research professorship (BOFZAP) at KU Leuven.

\footnotetext{
${ }^{67}$ For an interesting discussion of the hostility between traditional and mathematical logic, with a particular focus on the square of opposition that we already encountered earlier in this essay, cf. Jaspers and Seuren, op. cit. Religious context might also help to explain why the Lwów-Warsaw school in logic was relatively unaffected by the attempted Vergessenmachen. Because of their Catholic heritage, Polish logicians such as Jan Łukasiewicz (1878-1956) and the Dominican Józef M. Bocheński (19021995) maintained a vivid interest in Aristotelian logic, which they fruitfully combined with their work on mathematical logic. ${ }^{68}$ An analogous situation can be discerned in the historiography of Renaissance logic, where historians often take over the negative attitude vis-à-vis medieval logic from the humanist authors that they study; cf. footnote 48.
} 


\section{WORKS CITED}

Assmann, Aleida. 2016. Formen des Vergessens. Göttingen: Wallstein Verlag.

Barwise, Jon and Cooper, Robin. 1981. "Generalized Quantifiers and Natural Language." Linguistics and Philosophy 4 (2): 159-219.

Bird, Otto. 1963. “The History of Logic.” Review of Metaphysics 16 (3): 491-502.

Blum, Paul R. 2012. Studies on Early Modern Aristotelianism. Leiden \& Boston: Brill.

Boh, Ivan. 1993. Epistemic Logic in the Later Middle Ages. London: Routledge.

Braakhuis, H. A. G. and Kneepkens, C. H., eds. 2003. Aristotle's Peri Hermeneias in the Latin Middle Ages: Essays on the Commentary Tradition. Groningen-Haren: Ingenium.

Brumberg-Chaumont, Julie. 2015. "Universal Logic and Aristotelian Logic: Formality and Essence of Logic." Logica Universalis 9 (2): 253-79.

Burnett, Charles, ed. 1993. Glosses and Commentaries on Aristotelian Logical Texts: The Syriac, Arabic and Medieval Latin Traditions. London: Warburg Institute.

Carnap, Rudolf. 1937. The Logical Syntax of Language. London: Routledge \& Kegan Paul.

Coffey, Peter. 1912. The Science of Logic. London: Longmans, Green and Co.

Cohen, Daniel J. 2007. Equations from God: Pure Mathematics and Victorian Faith. Baltimore, MD: Johns Hopkins University Press.

Demey, Lorenz. 2016. "De dynamische wending in de epistemische logica." Tijdschrift voor Filosofie 78 (2): 365 91.

2018. "Computing the Maximal Boolean Complexity of Families of Aristotelian Diagrams." Journal of Logic and Computation 28 (6): 1323-39.

Demey, Lorenz and Smessaert, Hans. 2018. "Combinatorial Bitstring Semantics for Arbitrary Logical Fragments." Journal of Philosophical Logic 47 (2): 325-63.

De Morgan, Augustus. 1847. Formal Logic. London: Taylor and Walton.

Denifle, Henricus and Chatelain, Aemilio, eds. 1889. Chartularium Universitatis Parisiensis, Tomus I. Paris: Delalain.

Dimbath, Oliver. 2011. "Wissenschaftlicher Oblivionismus. Vom unbewussten zum strategischen Vergessen." In Soziologie des Vergessens. Theoretische Zugänge und empirische Forschungsfelder, edited by Oliver Dimbath and Peter Wehling, 297-316. Konstanz: Konstanzer Universitätsverlag.

- 2014. Oblivionismus: Vergessen und Vergesslichkeit in der modernen Wissenschaft. Konstanz: Konstanzer Universitätsverlag.

Dutilh Novaes, Catarina and Read, Stephen, eds. 2016. The Cambridge Companion to Medieval Logic. Cambridge: Cambridge University Press.

Ebbesen, Sten. 1992. "Western and Byzantine Approaches to Logic.” Cahiers de l'Institut du Moyen-Âge Grec et Latin 62: 167-178. 
2011. "What Counted as Logic in the Thirteenth Century?" In Methods and Methodologies: Aristotelian Logic East and West, 500-1500, edited by Margaret Cameron and John Marenbon, 93-107. Leiden \& Boston: Brill.

Eslick, Leonard, J. 1939. “Grammatical and Logical Form.” New Scholasticism 13 (3): 233-44.

Gabbay, Dov M. and Woods, John, eds. 2004-2014. Handbook of the History of Logic. 11 vols. Amsterdam: Elsevier.

Gasser, James. 2000. A Boole Anthology: Recent and Classical Studies in the Logic of George Boole. Dordrecht: Kluwer.

Grant, Edward. 1979. "The Condemnation of 1277, God's Absolute Power, and Physical Thought in the Late Middle Ages." Viator 10: 211-44.

Greenspan, Louis and Andersson, Stefan, eds. 1999. Russell on Religion. London: Routledge.

Guerlac, Rita. 1979. Juan Luis Vives Against the Pseudodialecticians: A Humanist Attack on Medieval Logic. Dordrecht: Reidel.

Haaparanta, Leila, ed. 2009. The Development of Modern Logic. Oxford: Oxford University Press.

Hintikka, Jaakko. 1962. Knowledge and Belief. An Introduction to the Logic of the Two Notions. Ithaca, NY: Cornell University Press.

2004. Analyses of Aristotle. Berlin: Springer.

Honderich, Ted. 1991. “An Interview with A. J. Ayer,” Royal Institute of Philosophy Supplement 30: $209-26$.

Jaspers, Dany and Seuren, Pieter A. M. 2016. "The Square of Opposition in Catholic Hands. A Chapter in the History of the 20th-Century Logic.” Logique et Analyse 59 (233): 1-35.

Kant, Immanuel. 1998. Critique of Pure Reason, translated by Paul Guyer and Allen W. Wood. Cambridge: Cambridge University Press.

Klima, Gyula. 2010. "Natural Logic, Medieval Logic and Formal Semantics.” Magyar Filozófiai Szemle 54 (4): 58-75.

Kneale, William and Kneale, Martha. 1962. The Development of Logic. Oxford: Clarendon Press.

Knuuttila, Simo. 1993. Modalities in Medieval Philosophy. London: Routledge.

Lamers, Han, Toon Van Hal and Bas Clercx. 2019. "How to Deal with Scholarly Forgetting: some starting points for discussion." History of Humanities \# (\#): \# \#.

Landini, Gregory. 2012. Frege's Notations: What They Are and How They Mean. London: Palgrave Macmillan.

Lear, Jonathan. 1980. Aristotle and Logical Theory. Cambridge: Cambridge University Press.

Lewry, Osmund. 1981. "The Oxford Condemnations of 1277 in Grammar and Logic." In English Logic and Semantics, edited by H. A. G. Braakhuis, C. H. Kneepkens and L. M. de Rijk, 235-78. Nijmegen: Ingenium.

de Libera, Alain. 1986. "La logique du moyen âge comme logique naturelle (Sprachlogik).” In Sprachphilosophie in Antike und Mittelalter, edited by Burkhard Mojsisch, 403-37. Amsterdam: Verlag B. R. Grüner.

Meyer, John-Jules Ch. and van der Hoek, Wiebe. 1995. Epistemic Logic for AI and Computer Science. Cambridge: Cambridge University Press. 
Øhrstrøm, Peter and Hasle, Per. 1995. Temporal Logic: From Ancient Ideas to Artificial Intelligence. Berlin: Springer.

Peckhaus, Volker. 1999. "19th Century Logic between Philosophy and Mathematics." Bulletin of Symbolic Logic 5 (4): $433-50$.

Prantl, Carl. 1855. 1861. 1867. 1870. Geschichte der Logik im Abendlande (4 volumes). Leipzig: S. Hirzel.

Prior, Arthur N. 1957. Time and Modality. Oxford: Clarendon Press. 1967. Past, Present and Future. Oxford: Clarendon Press.

Quine, Willard Van Orman. 1950. Methods of Logic. New York, NY: Holt, Rinehart and Winston.

Read, Stephen. 2012. “The Medieval Theory of Consequence.” Synthese 187 (3): 899-912.

2017. "Non-Normal Propositions in Buridan's Logic." In Formal Approaches and Natural Language in Medieval Logic, edited by Laurent Césalli, Frédéric Goubier and Alain de Libera, 453-68. Turnhout: Brepols.

Reck, Erich H., ed. 2002. From Frege to Wittgenstein: Perspectives on Early Analytic Philosophy. Oxford: Oxford University Press.

Rosenbloom, Paul C. 1950. The Elements of Mathematical Logic. New York, NY: Dover Publications.

Rosental, Creighton. 2018. "Aristotle's "Logical Worldview”: Understanding Logic Through Philosophy.” In Philosophical Perceptions on Logic and Order, edited by Jeremy Horne, 123-40. Hershey, PA: IGI Global.

Russell, Bertrand. 1946. The History of Western Philosophy. London: Allen and Unwin. 1968. The Art of Philosophizing and Other Essays. New York, NY: Philosophical Library.

Sluga, Hans D. 1980. Gottlob Frege. London: Routledge.

Smessaert, Hans and Demey, Lorenz. 2014. "Logical Geometries and Infomation in the Square of Oppositions." Journal of Logic, Language and Information 23 (4): 527-65.

Smith, Robin. 2018. “Aristotle's Logic.” In Stanford Encyclopedia of Philosophy (Spring 2018 edition), edited by Edward N. Zalta. Stanford, CA: CSLI.

Tabarroni, Andrea. 2003. "The 10th Thesis in Logic Condemned at Oxford in 1277." In Aristotle's Peri Hermeneias in the Latin Middle Ages. Essays on the Commentary Tradition, edited by H. A. G Braakhuis and C. H. Kneepkens, 339-61. Groningen-Haren: Ingenium.

Uckelman, Sara. 2010. "Logic and the Condemnations of 1277." Journal of Philosophical Logic 39 (2): 201-27. 2012. "Arthur Prior and Medieval Logic.” Synthese 188 (3): 349-66.

Westerståhl, Dag. 1989. “Aristotelian Syllogisms and Generalized Quantifiers.” Studia Logica 48 (4): 577-85.

Whitehead, Alfred North and Russell, Bertrand. 1910, 1912, 1913. Principia Mathematica (3 volumes). Cambridge: Cambridge University Press.

Williamson, Colwyn. 1971. “Traditional Logic as a Logic of Distribution-Values.” Logique et Analyse 14 (56): $729-46$

1988. “How Many Syllogisms Are There?” History and Philosophy of Logic 9 (1): 77-85.

Wittgenstein, Ludwig. 1993. Philosophical Occasions, 1912-1951. Indianapolis, IN: Hackett. 